Su labor posterior es demasiado conocida y Sánchez no nos aporta dato alguno de novedad. Amauta, Claridad, Labor, y toda la acción social de Mariátegui, están demasiado cercanas a nosotros para que las hayamos olvidado y para tener ya un historiador.

Después, ayer no más, su muerte llorada:

Tuve la noticia de su muerteleyendo la de su sepelio-el 19 de Abril en el Callao. A la velada en homenaje y en beneficio de sus hijos, acudió modestísima concurrencia, como a las conferencias de Frank. A su sepelio, una muchedumbre de obreros y estudiantes, con rojas banderolas y cantando $L a$ Internacional. De los homenajes rendidos a su memoria, el más significativo de todos ha sido el de la Argentina; luego el del Uruguay, el de Chile, y el de Cuba. En Estados Unidos se realiza también la colecta pro-hijos de Mariátegui. El más insignificante de los homenajes y el más incomprensivo, el de la prensa del Perú. Bueno es tener presente que en 1925 se propuso el nombre de José Carlos para una cátedra universitaria, de su especialidad, pero que se le vetó. Hay quien le ha enrostrado, después de muerto, el haber sido dueño de un bello estilo, sin reparar que más bella fué su actitud moral y que, bajo el estilo, afluía un pensamiento robusto $y$ definitivamente sistematizado y porvenirista. Para enterrar su cuerpo, hubo que realizar una colecta entre los amigos más allegados. Deja tres libros inéditos, varios hijos, el socialismo iniciado en el Perú y la discusión en torno a su figura. Además, un punto de concentración, pese a todas las discrepancias: fué un HOMBRE.

El homenaje a Mariátegui, a que se refiere Sánchez, en el bello estudio de que hemos dado cuenta, que se le hizo de parte de la intelectualidad cubana, está contenido en el N. 47 de 1930 , la revista de los escritores cubanos de avanzada. Escriben en él Waldo Frank, Juan Marinello, Lino Novás Calvo, Jorge Mañach, Adolfo Zamora, que da una impresión sobre Mariátegui, concisa y acertada, Félix Lizaso, Medardo Vitier y Francisco Ichaso. El número de 1930 a que nos referimos está completado por una sección destinada a los libros, en que se destaca una impresión crítica sobre El roto, la popular novela de Joaquín Edwards Bello.

\section{La SITUACIÓN CUBANa}

E1 N. 48 de la misma revista cubana trae, entre otros, un editorial debido a la pluma de Jorge Mañach, indicador del espíritu de la revista y significativo del actual estado político cubano. Se titula Economía, Política, Cultura y dice lo siguiente:

En la considerable reducción presupuestal que acaban de acordar nuestras Cámaras, quedan empequeñecidos notablemente los créditos afectos a la enseñanza pública. Supresión de cátedras, fusión peregrina de materias disímiles, rebaja, a límites increíbles, de la retribución profesoral, mantenimiento de planes incompletos e ineficaces, en vigor a título interino.

Como queda bien a las claras, una vez más la cultura no cuenta entre las preocupaciones de gobernantes y políticos. ¿Para qué tan gran cantidad de maestros, tanto catedrático inútil? se han dicho 
nuestros mandatarios. Gástese lo recaudado en ametralladoras relucientes, en vacua diplomacia, en conferencias y congresos decorativos e ineficaces. Vivamos como hasta aquí: no nos ha ido mal-han pensado nuestros políticos. $\mathrm{Y}$ no puede negarse que desde la mira de las conveniencias personales-única eminencia avizora de nuestra política-tienen plena razón. Por gran fortuna, parece que el pueblo empieza a creer que también a él la asisten sus razones.

1930, que con insistencia casi enfadosa ha venido clamando por una modernización integral de nuestra enseñanza, que ha venido señalando una y otra vez el lamentable anacronismo de nuestros planes y sistemas universitarios, ¿qué ha de decir ante resolución que aleja indefinidamente la esperanza de una seria reforma, qué ha de opinar sobre acuerdo que deja casi indotadas las enseñanzas experimentales superiores? Nadie ignora que en los laboratorios universitarios miles de alumnos quedan todos los años conociendo teóricamente el microscopio y realizando en los textos las experiencias químicas. ¿Que será ahora? No es un secreto que en Institutos y Escuelas Normales cada profesor se ha visto obligado a repetir hasta el agotamiento, durante cuatro y cinco horas diarias, el mismo disco. ¿Qué rendimientos estimables se obtendrán en lo adelan. te, mermada inverosímilmente la lista de esos profesores?

El más grave mal de nuestra enseñanza es, sin duda, la ninguna seriedad con que, por lo común, se realizan los estudios superiores, la ninguna autenticidad con que se prepara a los que han de impartir mañana, desde Institutos y Universidades, las más delicadas disciplinas. La solución casi nunca está en saber sino en «pasar». Privado el alumno en la segunda enseñanza, y en la superior, de estudios básicos para una cultura genuina, ve sólo ante sí un cuestionario de pre- guntas de examen que es necesario salvar a nado con el menor riesgo. $\mathrm{Si}$ se mantiene el risible ccurriculum > actual, si se recarga al profesor-hecho por lo común a la más enervadora rutina-con labores excesivas, si el material de estudio prácticamente desaparece, ¿qué caminos están reservados a nuestra cultura? Debe preocuparnos esto dolorosamente aunque los políticos criollos sigan contemplando nuestros graves problemas desde la «lomita» de su personales intereses.

Como se ve por el pensamiento transcrito, en Cuba, como en todas partes, se cuecen habas...

\section{PROUDHON COMO FILÓSOFO}

La Revue Bleue, conocida publicación francesa, en su número noveno del presente año trae un interesante estudio de Georges GuyGrand titulado ¿Proudhon es filósofo? En él, después de colocar al estudiado en la filosofía francesa del pasado siglo y ante la opinión generalmente despectiva de los filósofos contemporáneos, responde a la pregunta inicial en los siguientes términos:

Y si se toma la palabra filósofo en su acepción completa, pocos pensadores la merecen tanto como Proudhon. Pero es preciso entenderse. Sabemos ya lo que no es, lo que no dará. Para todo aquello que sea exposición o discusión puramente abstracta de sistemas, es imprudente fiarse a él. Si se quiere discutir a la manera de los metafísicos clásicos sobre la materia, la fuerza, la sustancia, sus formas o sus atributos, que no se le tome como guía. No es allí donde es original no hace más que repetir lecciones prematuras, asimiladas apresura- 